\title{
Learning Profile at SD 3 Banjar Sari During the Covid- 19 Pandemic
}

\author{
${ }^{1}$ Linda Feni Haryati, ${ }^{2}$ Nursaptini \\ ${ }^{1}$ lindafeni@unram.ac.id, 2nursaptini@unram.ac.id \\ 1, 2 Universitas Mataram
}

Received: November 2020

Accepted: November 2020

Online Published: Desember 2020

\begin{abstract}
Indonesia began to be affected by Covid-19 in early 2020, of course, this will give changes to all sectors of life. One sector that has also felt the impact is the education sector. On March 24, 2020, the Minister of Education and Culture of the Republic of Indonesia issued a government circular number 4 of 2020 concerning the Implementation of Education Policy in an Emergency for the Spread of COVID, by stipulating the provisions of the teaching and learning process starting from tertiary to basic education levels to be carried out online or learning at home. This distance learning course provides new challenges for teachers, students, and parents, in its implementation. This research aims to find out more clearly how the distance learning process and what obstacles are faced by teachers, students, and parents at SDN 3 Banjar Sari during the Covid-19 Pandemic. The method used in this research is qualitative research methods. This type of research uses a multi-case study design. Research results: the teacher has tried to do several learning methods, but until now there is no method that is considered the most effective in the teaching and learning process during the Covid-19 pandemic. Each method used by the teacher does not escape from various obstacles and shortcomings. Even so, teachers still try their best to carry out their duties in order to realize the goals of education.
\end{abstract}

Keyword: Learning Profiles, Learning during the Pandemic

\begin{abstract}
Abstrak
Indonesia mulai terdampak Covid-19 pada awal tahun 2020, hal ini tentunya memberi perubahan pada semua sektor kehidupan. Salah satu sektor yang juga merasakan dampaknya adalah pada sektor pendidikan. Pada tanggal 24 Maret 2020 Menteri Pendidikan dan Kebudayaan Republik Indonesia mengeluarkan surat edaran pemerintah Nomor 4 Tahun 2020 tentang Pelaksanaan Kebijakan Pendidikan dalam Masa Darurat Penyebaran COVID, dengan menetapkan ketentuan proses belajar mengajar mulai dari tingkat pendidikan tinggi hingga dasar dilakukan secara daring atau belajar di rumah. Pembelajaran jarak jarak jauh ini tentunya memberikan tantangan baru bagi guru, siswa dan orang tua murid, dalam pelaksanaanya. Penelitan ini bertujuan untuk mengetahui lebih jelas, bagaimana proses pembelajaran jarak jauh dan kendala apa saja yang dihadapi oleh guru, siswa dan orang tua, di SDN 3 Banjar Sari Pada Masa Pandemi Covid-19. Metode yang digunakan dalam penelitian ini adalah: metode penelitian kualitatif, Jenis penelitian ini menggunakan rancangan studi multi kasus. Hasli penelitian: guru sudah berusaha melakukan beberapa metode pembelajaran, namun hingga saat ini belum ada metode yang dirasa paling efektif, dalam proses belajar mengajar di masa pandemi covid-19 ini. Setiap metode yang digunakan oleh guru tak luput dari berbagai kendala dan kekurangan. Walaupun demikian, guru tetap berusaha semaksimal mungkin melaksanakan tugasnya guna mewujudkan tujuan Pendidikan.
\end{abstract}

Kata kunci: Profil Pembelajaran, Pembelajaran Masa Pandemi 


\section{INTRODUCTION}

Since the Covid-19 pandemic spread to various countries including Indonesia, millions of people have now been identified as positively exposed to the coronavirus in all parts of the world, from old age to children who have become victims of the spread of this virus. Indonesia began to be affected by Covid-19 in early 2020, of course, this will give changes to all sectors of life. One sector that is also experiencing its impact is the education sector. The government through the ministry of education and culture takes steps to anticipate early by establishing provisions for the teaching and learning process from tertiary to basic education to be carried out online or learning at home.

Efforts to prevent the spread of a massive and very fast epidemic have prompted the government through the Minister of Education and Culture to immediately make policies, considering that schools are places where large numbers of people gather. On March 24, 2020, the Minister of Education and Culture of the Republic of Indonesia issued government circular number 4 of 2020 concerning the Implementation of Education Policies in an Emergency for the Spread of covid. Students are not immediately closed during the Covid-19 pandemic, but they continue to study at home. This explains that the learning process from home is to be able to fulfill the rights of students in the form of educational services during the emergency response period, this is to protect members of the education unit from adverse effects, in order to break the chain of transmission and spread of the coronavirus.

The government does not remain silent, one of the efforts made by the government is to provide approximately 23 pages of learning resources that can be accessed by teachers, students, and parents, to study at home during the Covid-19 emergency period. The transfer of learning that was previously in school and now becomes learning at home, of course, has a profound impact on the teaching and learning process, teachers and students really feel the impact of the changes in the learning system from home. Each learning activity automatically switches to a distance and online learning system. Distance learning is a learning system that is implemented indirectly interacting or face to face. This distance learning course provides new challenges for teachers, students, and parents, in its implementation. In this distance learning process, teachers of course prepare various learning methods and tools such as cellphones, laptops, computers so that they can convey material. Teacher professionalism then becomes very important, because it is able to provide a positive role in developing student skills both through learning activities inside and outside the classroom (Saputra, 2015).

It is not as easy as imagined, challenges and obstacles are certainly experienced during this distance learning. This is due to the limitations of the ability of teachers and parents of students as providers of distance learning services at home. Limited supporting facilities such as mobile phones and internet signal constraints are one of the obstacles to this distance learning. One of the impacts of a new method is a cultural shock which then results in disruption of social adjustment in learning, disruption of achievement motivation, and interactions in the learning process that are not optimal (Ernofalina, 2017), (Pramudiana \& Setyorini, 2019). 
Another obstacle that also hinders the implementation of distance learning is the cost of adding internet quota that is charged to parents because internet network connection requires a lot of quotas, then parents also have to accompany their children while learning is taking place, this is in line with what was conveyed (Zaharah et al., 2020). Meanwhile, the obstacle for teachers is that not all teachers are proficient in using computer and internet technology during online or online learning. This online learning is not only applied in the capital city of Jakarta and Java, which has an extensive internet network, but also in areas outside Java.

West Nusa Tenggara Province is the central part of Indonesia which inevitably does online learning. The lack of facilities with other factors, is one of the challenges and obstacles in online learning. To find out more clearly, how the distance learning process is and what obstacles are faced by teachers, students, and parents, the researchers chose SD Negeri 3 Banjar Sari as the research site. SD Negeri 3 Banjar Sari is an elementary school located in the province of West Nusa Tenggara, precisely in East Lombok Regency, Labuan Haji District, with the majority of the local population as farmers and traders. To find out how the learning was during the covid era, the researchers raised an article entitled Learning Profiles at SDN 3 Banjar Sari during the Covid-19 Pandemic.

\section{METHODS}

The method used in this research is qualitative research methods. This type of research uses a multi-case study design (Creswell, 2014), which attempts to describe a specific setting, object, or event in detail and in-depth about learning at SDN 3 Banjar Sari during the covid-19 period. To obtain in-depth information and a wealth of descriptions, the researcher is directly involved as a key instrument in the research process. Data were collected through in-depth interviews with informants including principals, teachers, students, and parents. Researchers also collected documentation to support data obtained from sources or informants and the documents in question noted, photos of activities, and reports on the implementation of learning at SDN 3 Banjar Sari during the Covid-19 period. The data collection procedure uses the model proposed by (Miles, Huberman, 2014) which consists of four stages, namely: data collection, data presentation, data condensation, and drawing conclusions.

\section{RESULTS AND DISCUSSION}

SDN 3 Banjar Sari is one of the primary schools located in Labuhan Haji District, East Lombok Regency, West Nusa Tenggara Province. The number of students from grade 1 to grade 6 totaled 175 students and 15 teachers, staff, and school principals. With 6 study classrooms. Since the government issued a circular about learning during the Covid19 period, teachers and students of SDN 3 Banjar Sari have implemented learning using several learning methods. SDN 3 Banjar Sari teachers have tried several learning methods since the first lockdown was imposed until now. However, based on the results of 
interviews with teachers at SDN 3 Banjar Sari, until now there is still no teaching and learning method that is considered the most effective.

Based on the data obtained from the research results, during the covid pandemic, SDN 3 Banjar Sari has tried to apply 6 learning methods, presented in the following table:

Table 1. Learning Methods During Pandemic Covid

\begin{tabular}{llll}
\hline No & \multicolumn{1}{c}{ Method } & Teacher & \multicolumn{1}{c}{ Students } \\
\hline 1 & Online by WhatsApp Group & All teachers & Not all \\
2 & Go to Student's Home & Not all & Not all \\
3 & Learning from Home at TVRI & All teachers & Not all \\
4 & Study Groups at Home & Not all & Not all \\
5 & Distribution of worksheets & Not all & Not all \\
6 & One Hour School & All teachers & Not all \\
\hline
\end{tabular}

As for some of the learning methods during the covid-19 period carried out by SDN 3 Banjar Sari teachers and what obstacles they faced, were as follows:

1. Online Based Learning by WhatsApp Group

One of the online-based learning media used is WhatsApp or what is commonly abbreviated as WA. Learning with WA is an online communication tool that allows teachers to form virtual groups or classes, as a means to discuss, share learning materials, share assignments, quizzes, and check assignments. The WA group aims to make it easy and fast for teachers to convey information to parents. The importance of technology and information, apart from being a tool, is also a facilitator that supports the effectiveness of learning (Harun, 2015). However, in implementation, some obstacles and weaknesses are sometimes encountered, including:

1) There is no response from parents

Often times when teachers send assignments and materials, there is no response from parents. So that the teacher does not know for sure whether students have received the material or assignments given by the teacher. This fact is in line with research conducted by(Awang \& Daud, 2015) (Duta et al., 2015) that communication is an important variable in learning 
interactions and is related to effective learning goals, if communication is hampered, learning activities cannot run optimally.

2) Misunderstanding in receiving information

Misunderstanding in receiving this information could be caused by the written language used by the teacher, sometimes being shortened, or a typo. So that sometimes there are still many parents who then ask again about the assignment or material delivered. But there are also parents who don't ask questions and then when their children collect assignments, the assignments that are collected are not what the teacher expected.

3) Not all parents of students own a smartphone or android The work of the parents or guardians, who are mostly farmers and traders, so not all parents of students have androids. So that the teacher cannot at all provide material and assignments to students with constraints like this. Even though the teacher has informed the group WA that the parents of students who are neighbors of other students who do not have smartphones to deliver assignments, it seems that this is ignored by the parents of the students. This problem is not only faced by teachers at SD Banjar Sari, similar research also states that in elementary schools in Sukabumi, but not all students also have phones cellular (Putria et al., 2020).

4) There is no quota

The economic situation is getting more difficult due to the impact of the Covid-19 pandemic which has caused many parents to be unable to meet the needs of student learning quotas at any time. This is an obstacle that is also faced by teachers, and teachers cannot help solve this problem, because sometimes teachers also often run out of quotas.

2. Go to Student's Home

After the WA group method was deemed ineffective because many students could not take part in learning with this method, the SDN 3 Banjar Sari teacher tried to use a new method, namely by visiting the students' homes one by one. The teacher comes to the student's house to deliver photocopies of the material and assignments. But it is not as easy as imagined, there are several weaknesses and obstacles during its implementation, including:

1) Faraway student house

Students 'homes that are far from the teacher's house are one of the obstacles that make it difficult for teachers when visiting students' homes, there are even student houses that cannot be accessed by vehicles.

2) Time is not efficient

This time inefficient is caused by the large number of students, namely 175 students and 15 teachers. This is also an obstacle when visiting students' homes. In a day, the maximum teacher can only visit 10 houses. So that to 
visit the homes of all the student teachers it takes more than a week for one class.

3) Not all teachers can

Not all teachers can come to students 'houses because they have problems in not being able to use vehicles such as bicycles or motorbikes, so only a few students' houses that are close to their houses can be visited, while students whose homes are far away cannot be visited.

3. Learning from Home at TVRI

The Ministry of Education and Culture in April 2020 launched the Learning from Home program broadcast on national television TVRI. The Learning from Home Program is an alternative to learning in the Covid-19 pandemic. Minister of Education and Culture Nadiem Anwar Makarim wants to ensure that this condition does not cut off student opportunities to learn. This is done to anticipate if there are families who have limitations on internet access so that through television, it is hoped that it can help teachers, students, and also parents in learning from home during the pandemic. The weaknesses and constraints with this method are:

1) There is no TVRI channel It turns out that not all houses can access the TVRI channel, there are also some who can access the TVRI channel but the picture is not optimal. This then becomes an obstacle that this government program cannot be used by all students to learn.

2) Parental supervision.

It is not certain that when watching $\mathrm{TV}$, all students actually participate in learning on TV. In this case, parental supervision is very important, without strict supervision from parents, students can watch other TV broadcasts.

4. Study Groups at Home

The method that was then used by teachers during the Covid-19 pandemic, because they felt the previous method was less effective, was group study. The teacher forms a study group, one group consisting of 4-8 students whose houses are close together are collected in one student's house, the hope is that the teacher can teach students directly, and time is also considered more effective because the teacher does not need to visit the students' homes one by one. However, in the process of implementing this method, the obstacles faced by the teacher are:

1) Creating a crowd 
Seeing that there are teachers who come to the students' homes, and students study in groups, provoking other neighbors to be interested in seeing student activities, causing a crowd.

2) Warning From Citizens

This group learning method does not necessarily run smoothly, there is a crowd of residents and other children who witness the learning process as a group, then finally it results in a community warning to the teacher.

3) Not all teachers can

Not all teachers can come to students 'houses because they have problems in not being able to use vehicles such as bicycles or motorbikes, so only a few students' houses that are close to their houses can be visited, while students whose homes are far away cannot be visited.

5. Distribution of student worksheets (worksheets) in schools

The method than used by the teacher because he felt that the previous method was less effective, was to ask the parents of students to come to take Student Worksheets to school. This worksheet contains a summary of the material and a number of questions or assignments that students must do. The distribution of worksheets is carried out once a week and is scheduled, to anticipate the parents coming to school in groups. However, there are some weaknesses and obstacles faced by this method, namely:

1) Not all teachers provide worksheets

The limited ability of teachers to use computer technology has resulted in some teachers being unable to make worksheets to be distributed to students.

2) Students do not understand if it is not explained

After almost a month of using this method, the students' parents began to protest because their children could not do the LKS if it was not explained by the teacher. The limited ability of parents to assist their children in learning is one of the obstacles to this method.

6. One Hour School

After several methods were used and they were deemed ineffective, then the parents demanded that the school be active again, because the parents were unable to assist their children in learning, the school then agreed to do one hour 
of schooling. Within one hour, students are first asked to read books for a few minutes, then the teacher explains the learning material, then students are given assignments or practice questions. The provisions for this one hour school are:

a. Learning starts at 08: 00-09: 00 WITA.

b. Students and teachers must adhere to health protocols.

c. The student's sitting position is set at a distance.

d. Students have distributed masks.

e. The school provides a place for washing hands and soap.

f. There is no contact like shaking hands.

g. There are no hours of rest or play.

h. Canteen closed.

i. Students are given a group schedule provided that one group of 8-9 students is scheduled.

j. Students who are experiencing health problems, be it a serious illness or a minor illness such as flu, are not recommended to come to school.

The weaknesses and constraints of this method are:

1) Short time

a very short time makes the teacher feel unable to maximize in delivering learning material. The main difficulty is especially felt by upper-class mathematics teachers and low-grade Indonesian teachers.

2) Students feel bored

because school time is one hour, the school does not provide rest or play time for students, and the canteen is closed, this then makes students feel bored. Sometimes after studying and coming home from school, there are students who steal time to play in the schoolyard with their friends, but are immediately rebuked by the teacher and asked to return to their respective homes.

3) Students don't come

After so many months of not going to school, finally some students feel comfortable at home and feel lazy to come back to school.

Of the six learning methods carried out, until now there is no method that is considered the most effective that can be done by the SDN 3 Banjar Sari school, in the teaching and learning process during the Covid-19 pandemic. Every method used by teachers in teaching during the pandemic Covid-19 did not escape from various obstacles and shortcomings. This is similar to research conducted by Wahyono 2020, that the implementation of online learning has obstacles/obstacles both in terms of human resources and infrastructure, network limitations, lack of training, lack of awareness, and interest are stated as the main challenges faced. Even so, learning must continue, the 
teacher still tries as much as possible to carry out his duties in order to realize the goals of education (Wahyono et al., 2020)

\section{CONCLUTION}

Based on the results of the research conducted, it can be concluded that the teacher has tried to implement several learning methods, but until now there is no method that is considered the most effective that can be done by the SDN 3 Banjar Sari school, in the teaching and learning process during the Covid-19 pandemic. Every method used by teachers in teaching during the Covid-19 pandemic did not escape from various obstacles and shortcomings.

\section{ACKNOWLEDGMENTS}

The author would like to thank those who have helped and supported so that the author can complete this research. The author also expresses his gratitude for the prayers from my family, so that the author can finish this paper.

\section{REFERENCES}

Awang, H., \& Daud, Z. (2015). Improving a Communication Skill Through the Learning Approach Towards the Environment of Engineering Classroom. Procedia - Social and Behavioral Sciences, 195, 480-486. https://doi.org/10.1016/j.sbspro.2015.06.241

Creswell, J. W. (2014). Research design pendekatan kualitatif, kuantitatif dan mixed. Pustaka Pelajar.

Duta, N., Panisoara, G., \& Panisoara, I.-O. (2015). The Effective Communication in Teaching. Diagnostic Study Regarding the Academic Learning Motivation to Students. Procedia - Social and Behavioral Sciences, 186, 1007-1012. https://doi.org/10.1016/j.sbspro.2015.04.064

Ernofalina, E. (2017). Culture Shocks Experienced by Indonesian Students Studying Overseas. International Journal of Educational Best Practices, 1(2), 87. https://doi.org/10.31258/ijebp.v1n2.p87-105

Harun, I. (2015). Efektifitas Penggunaan Teknologi Informasi Dan Komunikasi Dalam Pembelajaran Pendidikan Agama Islam. POTENSIA: Jurnal Kependidikan Islam, 1(2), 175190. http://ejournal.uin-suska.ac.id/index.php/potensia/article/view/1449

Miles, Huberman, S. (2014). Qualitative Data Analysis A Methods Sourcebook. SAGE Publication.

Pramudiana, I. D., \& Setyorini, T. D. (2019). Hubungan Antara Gegar Budaya Dengan Penyesuaian $\begin{array}{lllll}\text { Sosial Siswa Papua di Magelang. Praxis, } 125 . & \end{array}$ https://doi.org/10.24167/praxis.v1i2.1631

Putria, H., Maula, L. H., \& Uswatun, D. A. (2020). Analisis Proses pembelajaran Dalam Jaringan (DARING) Masa Pandemi COVID-19 pada Guru Sekolah Dasar. Jurnal Basicedu, 4(4), 861872. https://doi.org/10.31004/basicedu.v4i4.460

Saputra, B. E. (2015). Peran Kultur Sekolah Dan Profesionalisme. 10(1), 147-157.

Wahyono, P., Husamah, H., \& Budi, A. S. (2020). Guru profesional di masa pandemi COVID-19: Review implementasi, tantangan, dan solusi pembelajaran daring. Jurnal Pendidikan Profesi Guru, 1(1), 51-65. http://ejournal.umm.ac.id/index.php/jppg/article/view/12462 
Zaharah, Kirilova, G. I., \& Windarti, A. (2020). Dampak wabah virus corona terhadap kegiatan belajar mengajar di Indonesia. Salam: Jurnal Sosial Dan Budaya Syar'i, 7(3), 269-282. http://journal.uinjkt.ac.id/index.php/salam/article/view/15104/0

Awang, H., \& Daud, Z. (2015). Improving a Communication Skill Through the Learning Approach Towards the Environment of Engineering Classroom. Procedia - Social and Behavioral Sciences, 195, 480-486. https://doi.org/10.1016/j.sbspro.2015.06.241

Creswell, J. W. (2014). Research design pendekatan kualitatif, kuantitatif dan mixed. Pustaka Pelajar.

Duta, N., Panisoara, G., \& Panisoara, I.-O. (2015). The Effective Communication in Teaching. Diagnostic Study Regarding the Academic Learning Motivation to Students. Procedia - Social and Behavioral Sciences, 186, 1007-1012. https://doi.org/10.1016/j.sbspro.2015.04.064

Ernofalina, E. (2017). Culture Shocks Experienced by Indonesian Students Studying Overseas. International Journal of Educational Best Practices, 1(2), 87. https://doi.org/10.31258/ijebp.v1n2.p87-105

Harun, I. (2015). Efektifitas Penggunaan Teknologi Informasi Dan Komunikasi Dalam Pembelajaran Pendidikan Agama Islam. POTENSIA: Jurnal Kependidikan Islam, 1(2), 175190. http://ejournal.uin-suska.ac.id/index.php/potensia/article/view/1449

Miles, Huberman, S. (2014). Qualitative Data Analysis A Methods Sourcebook. SAGE Publication.

Pramudiana, I. D., \& Setyorini, T. D. (2019). Hubungan Antara Gegar Budaya Dengan Penyesuaian Sosial Siswa Papua di Magelang. Praxis, 125. https://doi.org/10.24167/praxis.v1i2.1631

Putria, H., Maula, L. H., \& Uswatun, D. A. (2020). Analisis Proses pembelajaran Dalam Jaringan (DARING) Masa Pandemi COVID-19 pada Guru Sekolah Dasar. Jurnal Basicedu, 4(4), 861872. https://doi.org/10.31004/basicedu.v4i4.460

Saputra, B. E. (2015). Peran Kultur Sekolah Dan Profesionalisme. 10(1), 147-157.

Wahyono, P., Husamah, H., \& Budi, A. S. (2020). Guru profesional di masa pandemi COVID-19: Review implementasi, tantangan, dan solusi pembelajaran daring. Jurnal Pendidikan Profesi Guru, 1(1), 51-65. http://ejournal.umm.ac.id/index.php/jppg/article/view/12462

Zaharah, Kirilova, G. I., \& Windarti, A. (2020). Dampak wabah virus corona terhadap kegiatan belajar mengajar di Indonesia. Salam: Jurnal Sosial Dan Budaya Syar'i, 7(3), 269-282. http://journal.uinjkt.ac.id/index.php/salam/article/view/15104/0 